\title{
Efecto de Quitosan y Metabolitos de Trichoderma parareesei en el crecimieto de Fusarium oxysporum
}

\section{Effect of Chitosan and Metabolites of Trichoderma parareesei on Fusarium oxysorum growth}

\author{
Hernández-Domínguez, $C .{ }^{1}$, Vázquez-Moreno, $F .{ }^{1}$, Cruz-Pantoja, A. J. ${ }^{2}$, \\ Orduño-Cruz, N. ${ }^{3}$, Domínguez-Perales, L. A. ${ }^{1}$, Vázquez-Cruz, F. ${ }^{1}$.
}

${ }^{1}$ Facultad de Ingeniería Agrohidráulica, Benemérita Universidad Autónoma de Puebla. Av. Universidad S/N, San Juan Acateno, Teziutlán Puebla 73965, México; ' Instituto Tecnológico Superior de Zacapoaxtla, carretera Acuaco-Zacapoaxtla Km. 8, Col. Totoltepec, 73680, Zacapoaxtla Puebla, México. ${ }^{3}$ Facultad de Ciencias Agrotecnológicas, Universidad Autónoma de Chihuahua, México.

Cite this paper/Como citar este artículo: Hernández-Domínguez, C., Vázquez-Moreno, F., CruzPantoja, A. J., Orduño-Cruz, N., Domínguez-Perales, L. A., Vázquez-Cruz, F. (2021). Effect of Chitosan and Metabolites of Trichoderma parareesei on Fusarium oxysorum growth. Revista Bio Ciencias, e867. doi: https://doi.org/10.15741/revbio.08.e867

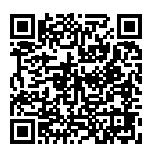

\begin{abstract}
A B S TRACT
Information about the effects of antimicrobial and antagonistic products on the growth of phytopathogens is pivotal in agriculture to achieve effective management strategies in the field or greenhouse. This research aimed to analyze the in vitro growth and antagonism of Trichoderma parareesei and Fusarium oxysporum when exposed to different concentrations of chitosan $(1,4,6,8,10$, and $12 \mathrm{mg}$ - $\left.\mathrm{mL}^{-1}\right)$. Such dosages were supplemented with metabolites of $T$. parareesei filtered on cellophane paper and adhered to the culture medium on which the phytopathogen was grown. The diffusion of metabolites at each dose was evaluated prior tto incorporating $F$. oxysporum. Obtained data showed significant difference between the growth and inhibition of the fungi on chitosan $\left(\mathrm{F}_{5,35}=4.47, p<0.001\right)$, the dose of $1 \mathrm{mg} \cdot \mathrm{mL}^{-1}$ induced greater mycelial growth
\end{abstract}

\section{Article Info/Información del artículo}

Received/Recibido: November $13^{\text {th }} 2019$.

Accepted/Aceptado: July 03 2021.

Available on line/Publicado: July $27^{\text {th }} 2021$.

\section{RE S U MEN}

Conocer el efecto de productos antimicrobianos y antagonistas sobre el crecimiento de fitopatógenos es de relevancia en la agricultura al integrarlos como estrategia de manejo en campo o invernadero. El objetivo de este trabajo fue analizar el crecimiento y antagonismo in vitro de Trichoderma parareesei y Fusarium oxysporum sobre diversas concentraciones de quitosan $(1,4,6,8,10$, y 12 $\mathrm{mg} \cdot \mathrm{mL}^{-1}$ ). Estas mismas dosis fueron suplementadas con metabolitos de $T$. parareesei filtrados en papel celofán adherido al medio de cultivo sobre el cual se creció el fitopatogeno. La difusión de metabolitos en cada dosis fue evaluada antes de incorporar a F. oxysporum. Los resultados del análisis estadístico mostraron diferencia significativa entre el crecimiento e inhibición de los hongos sobre quitosan $\left(\mathrm{F}_{5,35}=4.47, p<0.001\right)$, la dosis de $1 \mathrm{mg} \cdot \mathrm{mL}^{-1}$ indujo mayor crecimiento de micelio en el fitopatogeno, disminuyendo conforme incrementó la dosis de quitosan. Para el caso $T$. parareesei las dosis utilizadas no limitaron su desarrollo y crecieron $93 \%$ más que $F$. oxysporum, y la mayor inhibición para ambos casos fueron 6 y $12 \mathrm{mg} \cdot \mathrm{mL}^{-1}$. El área de

\section{*Corresponding Author:}

Carmela Hernández-Domínguez. Facultad de Ingeniería Agrohidráulica, Benemérita Universidad Autónoma de Puebla. Av. Universidad S/N, San Juan Acateno, Teziutlán Puebla 73965, México. Phone: (595) 95289 69. E-mail: Carmela.hernandezd@correo.buap.mx 
on the phytopathogen, decreasing as the dose of chitosan increased. In the case of $T$. parareesei, the doses used did not limit its development and growth $93 \%$ more than $F$. oxysporum, and the greatest inhibition for both cases were achieved with 6 and $12 \mathrm{mg} \cdot \mathrm{mL}^{-1}$. The area of diffusion of metabolites of $T$. parareesei increased in relation to the chitosan dose, and although this was not related to the reduction of $F$. oxysporum growth, there was a synergistic effect between chitosan and secondary metabolites.

\section{KEY W ORD S}

Antagonists, antimicrobials, dose, phytopathogens,
reduction.

\section{Introduction}

Vascular wilt caused by Fusarium oxysporum is one of the diseases that most affect crops, causing considerable losses (De Granada et al., 2001). Due to its importance, several researchers have searched for alternatives for its management, however, the results have been unsuccessful. Therefore, nowadays researchers are focusing on options such as biological and natural methods to ameliorate the damage caused by this fungus.

In this regard, studies with antifungal agents of natural origin, such as chitosan, have been studied in the management of phytopathogenic fungi due to some attributable antimicrobial activities (Roller \& Covill, 2000; Allan \& Hardwiger, 1979). In accordance with the above, authors such as Prapagdee et al. (2007) have reported inhibition of spore germination of Penicillium expansum, Botrytis cinerea and Fusarium solani $\mathrm{f}$. sp. glycines by chitosan. Additional data are provided by Guo et al. (2006), who linked the high molecular weight of chitosan with the inhibition of mycelial growth of Fusarium oxysporum, Alternaria solani and Valsa mali, Palma-Guerrero et al. (2008); Rabea et al. (2009) observed inhibition of spore germination of Fusarium oxysporum and Verticillium dahliae up to 90 and 100 $\%$ respectively. Similarly, Hernandez-Lauzardo et al. (2008); Singh et al. (2008) reported that increasing chitosan concentration causes excessive branching, vacuolation and reduction of hyphal diameter, the most effective concentrations being 1.5 and $2.0 \mathrm{mg} \cdot \mathrm{mL}^{-1}$ difusión de metabolitos de T. parareesei se incrementó en relación a la dosis de quitosan evaluada, y aunque esta no tuvo relación con la reducción del crecimiento de $F$. oxysporum, hubo un efecto sinergista entre el quitosan y metabolitos secundarios.

\section{PALABRAS CLAVE}

Antagonistas, antimicrobianos, dosis, fitopatógenos, reducción.

\section{Introducción}

El marchitamiento vascular ocasionado por Fusarium oxysporum, es una de las enfermedades que más afecta a los cultivos ocasionando pérdidas considerables (De Granada et al., 2001). Debido a su importancia, varios investigadores han buscado alternativas para su manejo, sin embargo, los resultados han sido pocos exitosos, de ahí que en la actualidad se siguen buscando opciones como los métodos biológicos y naturales para contrarrestar el daño por este hongo.

Al respecto, estudios con agentes antifúngicos de origen natural, tales como el quitosan han sido estudiados en el manejo de hongos fitopatógenos debido a las propiedades antimicrobianas que posee (Roller \& Covill, 2000; Allan \& Hardwiger, 1979). Así mismo, autores como Prapagdee et al. (2007) han reportado inhibición en la germinación de esporas de Penicillium expansum, Botrytis cinerea y Fusarium solani f. sp. glycines por este agente microbiológico. Otros resultados son los proporcionados por Guo et al. (2006), quienes observaron que el quitosan de alto peso molecular causó la inhibición del crecimiento del micelio de Fusarium oxysporum, Alternaria solani y Valsa mali, Palma-Guerrero et al. (2008); Rabea et al. (2009) observaron inhibición de la germinación de esporas de Fusarium oxysporum y Verticillium dahliae hasta 90 y $100 \%$ respectivamente. De igual manera, HernándezLauzardo et al. (2008); Singh et al. (2008) observaron que el incremento en la concentración provoca excesivas ramificaciones, vacuolación y reducción del diámetro de hifas siendo las concentraciones más efectivas 1.5 y 2.0 $\mathrm{mg} \cdot \mathrm{mL}^{-1}$.

A pesar de que hay estudios del efecto antimicrobiano de este biopolímero, los resultados indican una respuesta variable y depende del grado de deacetilación, 
Previous studies of the antimicrobial effect of this biopolymer indicated a variable response associated to the deacetylation degree, molecular concentration and cellular response of the treated microorganism, there were also described biological effectiveness for some fungi and tolerance for others such as Trichoderma (Rabea et al., 2009). The Trichoderma genus comprises fungi with great potential in the management of several phytopathogenic fungi including Fusarium oxysporum wich is poorly affected by chitosan (Melia \& Ariantha, 2010; Abou et al., 2007), such features make them suitable for studies of additive or synergistic effects using chitosan. However, the combination of secondary metabolites with chitosan has been little studied and the antagonistic and synergistic reactions of these mixtures are still unknown; for this reason, this work aimed to analyze the growth of Fusarium oxysporum on secondary metabolites of Trichoderma parareseei with different doses of chitosan.

\section{Material and Methods}

\section{Obtaining strains}

The strains VB19IF1 belonging to Fusarium oxysporum and VB10IT2 to Trichoderma parareesei obtained from the collection of the Faculty of Agrohydraulic Engineering of the Benemérita Universidad Autónoma de Puebla were used, and then they were propagated on Potato Dextrose Agar (PDA; brand MCD-Lab) at $31 \pm 2{ }^{\circ} \mathrm{C}$ during four days.

\section{Growth of $F$. oxysporum and T. parareesei on chitosan}

Six concentrations of chitosan (Table 1) (SigmaAldrich, $85 \%$ distillation grade) were used for the experiment and then mixed with PDA culture medium in Petri dishes. After 24 hours at room temperature, $0.5 \mathrm{~cm}$ diameter circles of 4-day-old F. oxysporum and T. parareesei growth were placed in the center of each Petri dish, ensuring that the mycelium remained in contact with the medium. The control consisted of seeding both fungi on Sabouraud Dextrose Agar (SDA) medium without chitosan. All plates were incubated at $31 \pm 2{ }^{\circ} \mathrm{C}$ until the control filled the Petri dish. Growth was measured every 24 hours through photographs obtained with a scanner (Epson L575), which were edited with the Gim Map software (Version 2.8), and the growth diameter was determined with the Image tool software (version 3.0). concentración molecular y respuesta celular del microorganismo tratado, observándose efectividad biológica para algunos hongos y tolerancia para otros como Trichoderma (Rabea et al., 2009). El género Trichoderma es un hongo con gran potencial en el manejo de varios hongos fitopatógenos incluyendo Fusarium oxysporum y es poco afectado por quitosan (Melia \& Ariantha, 2010; Abou et al., 2007) características que lo hacen un buen candidato para realizar estudios de efecto aditivo o sinergico con el biopolimero. Sin embargo, la combinación de metabolitos secundarios con quitosan, ha sido poco estudiado y se desconocen las reacciones antagonicas y sinergicas al realizare estas mezclas, por lo tanto, éstas deberían ser analizadas más a fondo. Por lo anterior, el objetivo de este trabajo fue analizar el crecimiento de Fusarium oxysporum en metabolitos secundarios de Trichoderma parareseei y diferentes dosis de quitosan.

\section{Material y Métodos}

\section{Obtención de cepas}

Se utilizaron las cepas VB19IF1 perteneciente a Fusarium oxysporum y VB10IT2 a Trichoderma parareesei obtenidas de la colección de la Facultad de Ingeniería Agrohidráulica de la Benemérita Universidad Autónoma de Puebla, las cuales fueron propagadas Agar Dextrosa Papa (PDA; marca MCD-Lab) a $31 \pm 2{ }^{\circ} \mathrm{C}$ por 4 días.

\subsection{Crecimiento de F. oxysporum y T. parareesei sobre quitosan}

Para el experimento se emplearon seis concentraciones de quitosan (Tabla 1) (Sigama-Aldrich, $85 \%$ grado de destilación) las cuales se mezclaron con medio de cultivo PDA en cajas Petri. Después de 24 horas mantenidas a temperatura ambiente, círculos de $0.5 \mathrm{~cm}$ de diámetro del crecimiento de F. oxysporum y $T$. parareesei de cuatro días de edad fueron colocados en el centro de cada caja Petri, procurando que el micelio quedara en contacto con el medio. El testigo consistió en sembrar ambos hongos en medio Agar Dextrosa Sabouraud (SDA) sin quitosan. Todas las cajas fueron incubadas a $31 \pm 2$ ${ }^{\circ} \mathrm{C}$ hasta que el testigo llenara la caja. El crecimiento fue medido cada 24 horas a través de fotografías obtenidas con un escáner (Epson L575), las cuales fueron editadas con el programa Gim Map (Versión 2.8), y el diámetro de crecimiento fue determinado con el programa Image tool (versión 3.0). 


\section{Growth of $F$. oxysporum in the presence of chitosan and secondary metabolites of $T$. parareesei.}

For the evaluation of secondary metabolites, PDA culture medium was prepared with six different concentrations of chitosan (Table 1), each treatment obtained was placed in Petri dishes, and a $90 \mathrm{~cm}$ diameter circle of cellophane paper was placed on the culture medium of each dish, then all treatments were stored for 24 hours at room temperature.

Thereafter, $0.5 \mathrm{~cm}$ circles of $T$. parareesei were incorporated and grown at $31 \pm 2{ }^{\circ} \mathrm{C}$ for 48 hours on the cellophane paper in the center of each dish. Subsequently, the growth was stopped by removing the cellophane paper, leaving the filtered Trichoderma metabolites on the culture medium. The area occupied by the metabolites was observed under UV light and measured through photographs captured with a Bio-Rad Gel Doc 2000 equipment (CCD camera, Bio-Rad). The photographs were edited and measured according to the methodology mentioned in the previous section. Subsequently, in the center of the area occupied by the filtered metabolites, $0.5 \mathrm{~cm}$ diameter circles with fourday-old $F$. oxysporum growth were placed and incubated at $31 \pm 2{ }^{\circ} \mathrm{C}$ until the control filled the Petri dish. Growth was measured following the methodology mentioned in the previous section.

\section{Experimental design and statistical analysis}

In all assays, a completely randomized experimental design was used, each treatment included four replicates and two replicates simultaneously. The fungal growth data were analyzed through ANOVA and Tukey mean comparison tests with a significance level $p$ $<0.001$ using SAS statistical package (Version 9.0) for Windows. To determine the percentage inhibition of mycelial development (PID), the formula was used, where: DMtrat= mycelial development in the treatment with chitosan, DMTA = mycelial development in the absolute control. To assess the association between the growth area of $F$. oxysporum and the area of metabolite diffusion, a simple regression analysis was performed taking the experimental units that presented different areas of metabolite diffusion, but equal doses of chitosan.

The synergy (SF) between T. parareesei (Tp3) and chitosan (Qs11) was evaluated using Bliss independence model (Xuet et al., 2011). The expected percentage of disease development for combined use (Tp3, Qs) was calculated as

\section{Crecimiento de $F$. oxysporum en presencia de quitosan y metabolitos secundarios de $T$. parareesei.}

Para la evaluación de metabolitos secundarios se preparó medio de cultivo PDA con seis diferentes concentraciones de quitosan (Tabla 1), cada tratamiento obtenido fue colocado en cajas Petri, y sobre el medio de cultivo de cada caja se colocó un círculo de $90 \mathrm{~cm}$ de diámetro de papel celofán, posteriormente todos los tratamientos fueron almacenados por 24 horas a temperatura ambiente.

Transcurrido el tiempo, círculos de $0.5 \mathrm{~cm}$ de $T$. parareesei fueron incorporados y crecidos a $3 \pm 2{ }^{\circ} \mathrm{C}$ por 48 horas sobre el papel celofán en el centro de cada caja. Posteriormente, el crecimiento fue retirado al quitar el papel celofán, quedando sobre él medio de cultivo los metabolitos filtrados de Trichoderma. El área ocupada por los metabolitos fue observada en luz ultravioleta y medida a través de fotografías tomadas con un equipo Bio-Rad Gel Doc 2000 (cámara CCD, Bio-Rad). Las fotografías fueron editadas y medidas de acuerdo a la metodología mencionada en el apartado anterior. Posteriormente, en el centro del área ocupada por los metabolitos filtrados, se colocaron círculos de $0.5 \mathrm{~cm}$ de diámetro con crecimiento de $F$. oxysporum con cuatro días de edad, los cuales fueron incubados a $31 \pm 2{ }^{\circ} \mathrm{C}$ hasta que el testigo llenara la caja. Todos los crecimientos fueron medidos de acuerdo a la metodología mencionada en el apartado anterior.

\section{Diseño experimental y análisis estadísticos}

En todos los ensayos se realizó un diseño experimental completamente al azar, cada tratamiento con cuatro replicas y dos repeticiones en tiempo. Los datos de crecimiento de los hongos se sometieron a un análisis de varianza (ANOVA) y prueba de comparación de medias Tukey con un nivel de significancia $p<0.001$ con el paquete estadístico SAS para Windows (Versión 9.0). Para determinar el porcentaje de inhibición del desarrollo micelial (PID) se utilizó la formula , donde: DMtrat = Desarrollo micelial en el tratamiento con quitosan, DMTA = Desarrollo micelial en el testigo absoluto. Con el fin de conocer la asociación entre el área de crecimiento de $F$. oxysporum y el área de difusión de metabolitos se realizó un análisis de regresión simple tomando las unidades experimentales que presentaron diferente área de difusión de metabolitos, pero igual dosis de quitosan.

La sinergia (SF) entre $T$. parareesei (Tp3) y quitosan (Qs11) se evaluó utilizando la independencia de Bliss 
the product of two individual control agents (CA) (Tp3 and Qs11) (i.e., Tp3, Qs11 = Tp3 $\times$ Qs11). If treatment efficacy is defined as ETp3, Qs11 = 1- Tp3, Qs11, then 1-ETp3 / Qs11 = (1-ETp3) $\times(1-E Q s 11)$. The algebraic simplification of this equation derives from the formula used: ETp3, Qs11 $=E T p 3+E Q s 11-(E T p 3 \times E Q s 11)(X u$ et al., 2011). When $\mathrm{SF}=1$, the interaction between $\mathrm{CA}$ is additive; when $\mathrm{SF}$ $<1$, the interaction is antagonistic; and when $S F>1$, the interaction is synergistic.

\section{Results and Discussion}

\section{Growth of Fusarum oxysporum and} Trichoderma parareesei on chitosan.

The analysis of fungal growth on chitosan doses showed a statistical difference $\left(\mathrm{F}_{5,35}=4.47, p<0.001\right)$, the dose of $1 \mathrm{mg} \cdot \mathrm{mL}^{-1}$ induced greater mycelial growth in the phytopathogen, decreasing as the chitosan dose increased (Table 1). Abou et al. (2007) found a correlation between growth and dose, i.e. the higher the dose, the lower the growth of $F$. oxysporum, however, in this study such codependence was not evident. A research conducted by Al-Hetar et al. (2011) shows the effect of chitosan on the growth of F. oxysporum f. sp. cubense Race 4, highlighting the morphological changes and low emergence of germ tubes. Similar results were reported by Melia \& Ariantha (2010), when working with chitosan they found mutations in F. oxysporum and Trichoderma, as well as greater effectiveness in doses higher than $2.5 \%$.

Regarding the growth of $T$. parareesei, all the doses used in this experiment had a similar effect to the control, i.e., no dose of chitosan limited mycelial development (Table 1). Abou et al. (2007), Chittenden \& Singh (2009), who observed growth of $T$. harzianum at different doses of chitosan and found no lethal response to the doses tested; however, the mutants obtained from these strains changed their antagonistic action, highlighting their growth at doses of 3.00 and $4.50 \mathrm{mg} \cdot \mathrm{mL}^{-1}$.

On the other hand, the percentage of inhibition of the biopolymer according to the doses evaluated on the phytopathogen and antagonist was different, the highest inhibition for both cases were between 6 and $12 \mathrm{mg} \cdot \mathrm{mL}^{-1}$ with a percentage of 12.6 and $9.3 \%$ for $F$. oxysporum, while T. parareesei presented 11 and $18 \%$ (Figure 1). These results are possible since chitosan has fungicidal properties. In this regard, Roller \& Covill, (2000)
(Xuet et al., 2011). El porcentaje esperado del desarrollo de la enfermedad para uso combinado (Tp3, Qs) se calculó como el producto de dos agentes de control (CA) individuales (Tp3 y Qs11) (es decir, Tp3, Qs11 = Tp3 $\times$ Qs11). Si la eficacia del tratamiento se define como ETp3, Qs11 = 1- Tp3, Qs11, entonces 1-ETp3 / Qs11 = (1-ETp3) $\times$ (1-EQs11). La simplificación algebraica de esta ecuación deriva de la fórmula utilizada: ETp3, Qs11 = ETp3 + EQs11 - (ETp3 × EQs11) (Xu et al., 2011). Cuando SF = 1 , la interacción entre los CA es aditiva; cuando $S F<1$, la interacción es antagónica; y cuando SF > 1, la interacción es sinérgica.

\section{Resultados y Discusión}

\section{Crecimiento de Fusarum oxysporum y Trichoderma parareesei sobre quitosan.}

El análisis de crecimiento de los hongos sobre las dosis de quitosan mostró diferencia estadística $\left(F_{5^{\prime} 35}=4.47\right.$, $p<0.001$ ), la dosis de $1 \mathrm{mg} \cdot \mathrm{mL}^{-1}$ indujo mayor crecimiento de micelio en el fitopatogeno, disminuyendo este conforme incrementó la dosis de quitosan (Tabla 1). Al respecto Abou et al. (2007) encontraron una correlación entre el crecimiento y dosis, es decir a mayor dosis disminuyó el crecimiento de F. oxysporum, sin embargo, en éste estudio esta codependecia no fue tan clara. Estudios realizados por Al-Hetar et al. (2011) muestran el efecto de quitosan sobre el crecimiento de F. oxysporum f. sp. cubense Raza 4 , estos autores destacan los cambios morfológicos y baja emergencia de tubos germinativos. Resultados similares fueron reportados por Melia \& Ariantha (2010), al trabajar con éste biopolímero encontraron mutaciones en $F$. oxysporum y Trichoderma, así como una mayor efectividad en dosis mayores a $2.5 \%$.

Con respecto al crecimiento de T. parareesei, todas las dosis utilizadas en éste experimento tuvieron efecto similar al testigo, es decir, ninguna dosis de quitosan limito el desarrollo del micelio (Tabla 1). Estos resultados concuerdan con los obtenidos por Abou et al. (2007), Chittenden \& Singh, (2009), quienes observaron crecimiento de $T$. harzianum en dieferentes dosis de quitosan no encontrando respuesta letal a las dosis probadas, sin embargo los mutantes obtenidos de éstas cepas cambiaron su acción antagónica, resaltando su crecimiento con dosis de 3.00 y $4.50 \mathrm{mg} \cdot \mathrm{mL}^{-1}$.

Por otra parte, el porcentaje de inhibición del biopolímero de acuerdo a la dosis evaluadas sobre el fitopatógeno y 
Table 1

Growth of $F$. oxysporum and $T$. parareesei on SDA medium with chitosan.

Tabla 1.

Crecimiento de F. oxysporum y T. parareesei en medio SDA con quitosán.

\begin{tabular}{ccc}
\hline Treatments & \multicolumn{3}{c}{ Growth $\left(\mathrm{Cm}^{2}\right)$} \\
\hline (Doses of chitosan) & Fusarium oxysporum & Trichoderma parareesei \\
\hline $1 \mathrm{mg} \cdot \mathrm{mL}^{-1}$ & $5.91^{\mathrm{a}}$ & $50.26^{\mathrm{a}}$ \\
$4 \mathrm{mg} \cdot \mathrm{mL}^{-1}$ & $3.42^{\mathrm{b}}$ & $50.26^{\mathrm{a}}$ \\
$6 \mathrm{mg} \cdot \mathrm{mL}^{-1}$ & $3.14^{\mathrm{b}}$ & $45.01^{\mathrm{a}}$ \\
$8 \mathrm{mg} \cdot \mathrm{mL}^{-1}$ & $3.31^{\mathrm{b}}$ & $50.26^{\mathrm{a}}$ \\
$10 \mathrm{mg} \cdot \mathrm{mL}^{-1}$ & $2.77^{\mathrm{b}}$ & $46.62^{\mathrm{a}}$ \\
$12 \mathrm{mg} \cdot \mathrm{mL}^{-1}$ & $2.62^{\mathrm{b}}$ & $41.42^{\mathrm{a}}$ \\
$\mathrm{control}$ & $3.09^{\mathrm{b}}$ & $50.26^{\mathrm{a}}$ \\
\hline
\end{tabular}

suggest that there is less effectiveness in fungi that bear chitosan in its cell wall, for example it is known that the cell wall of $F$. oxysporum presents FIS, 3-gluco-galactomannan of complex structure, FII, $p$-1,3-glucan and F4, complex formed by chitin and B-1,3-glucan (Alfonso et al., 1992); therefore, such fungi should be sensitive to this biopolymer given that its natural presence does not generate adverse effects for these microorganisms (Lárez, 2008). In addition, to observe its effectiveness in both cases it is necessary to find the appropriate dose for each situation, as well as to carry out detailed studies for the different development stages, since recent studies have shown that chitosan is more effective on conidia than on the hyphae of some phytopathogenic fungi (Palma-Guerrero et al., 2008). antagonista fue diferente, la mayor inhibición para ambos casos fueron 6 y $12 \mathrm{mg} \cdot \mathrm{mL}^{-1}$ con un porcentaje de 12.6 y $9.3 \%$ para el caso de $F$. oxysporum, mientras que para $T$. parareesei fue de 11 y $18 \%$ (Figura 1). Estos resulados son posibles debido a que quitosan posee cualidades fungicidas que inhiben diversas especies de hongos. Al respecto, Roller \& Covill, (2000) sugieren que existe menos efectividad en aquellos que lo poseen en su pared celular por ejemplo se conoce que la pared celular de $F$. oxysporum presenta FIS, 3-gluco-galacto-manano de estructura compleja, FII , p-1,3-glucano y F4, complejo formado por quitina y B-1,3-glucano (Alfonso et al., 1992) por lo que éste hongos deberían ser sensibles a éste biopolímero debido a que su presencia natural no genera efectos adversos para estos microorganismo (Lárez, 2008), por lo tanto, para observar su efectividad en ambos casos se deberá encontrar la dosis adecuada para cada situación, así como realizar estudios

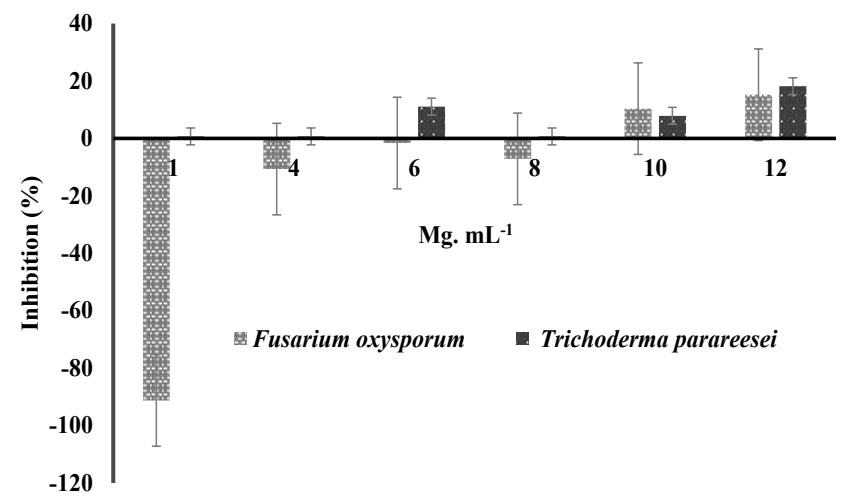

Figure 1. Growth inhibition of $F$. oxysporum and $T$. parareesei on SDA medium with different doses of chitosan.

Figura 1. Inhibición de crecimiento de F. oxysporum y T. parareesei en medio SDA con diferentes dosis de quitosan. 
With respect to Trichoderma, Kowsari et al. (2014), showed that this fungus treated with doses higher than $1 \%$ of chitosan can undergo mutations and expresses the chitinase gene, which makes them more effective in the control of phytopathogenic diseases, however it is necessary to perform additional physiological and morphological studies to evaluate potential adverse effects of the biopolymer on Trichoderma.

Growth of $F$. oxysporum in the presence of chitosan and secondary metabolites of $T$. parareesei

A statistical difference was observed between the area occupied by metabolites diffused from $T$. parareesei at different doses $\left(\mathrm{F}_{5,23}=4.61, p<0.001\right)$, finding that the higher the dose, the greater the area occupied by metabolites (Figure 1), maintaining this tendency up to a dose of $10 \mathrm{mg} \cdot \mathrm{mL}^{-1}$. Similar results were found by Sandhya et al. (2005) who determined that $0.5 \%$ colloidal chitin can enhance the production of chitinases in T. harzianum.

Moreover, the correlation analysis shows a medium association between the area of metabolite diffusion and the growth of $F$. oxysporum $(R=0.3754)$. This suggests that the effect on the reduction of $F$. oxysporum growth when exposed to secondary metabolites of Trichoderma plus chitosan does not depend on the amount of metabolites diffused in the medium, but factors such as the concentration and type of metabolites secreted and the dose of chitosan added must be considered (Figure 2). detallados para los diverso estados de desarrollo, debido a que estudios recientes han demostrado que quitosan es más efectivo sobre conidios que sobre las hifas de algunos hongos fitopatógenos (Palma-Guerrero et al., 2008).

Para el caso de Trichoderma, Kowsari et al. (2014), muestran que este hongo tratado con dosis superiores a $1 \%$ de quitosan es capaz de sufrir mutaciones y expresa el gen de la quitinasa, lo que los hace más efectivos en el control de enfermedades fitopatógenas, sin embargo, es necesario realizar estudios fisiológicos y morfológicos que descarten la posibilidad de un efecto adverso del biopolimero sobre Trichoderma.

\section{Crecimiento de F. oxysporum en presencia de} quitosan y metabolitos secundarios de $T$.

parareese $i$

Se observó diferencia estadística entre el área ocupada por metabolitos difundidos de $T$. parareesei en diferentes dosis $\left(F_{5,23}=4.61, p<0.001\right)$, encontrando que a mayor dosis mayor área ocupada por metabolitos (Figura 1), manteniendo esta tendencia hasta la dosis de $10 \mathrm{mg} \cdot \mathrm{mL}^{-1}$. Resultados similares fueron encontrados por Sandhya et al. (2005) quienes determinaron que la quitina colloidal al $0.5 \%$ es capaz de potenciar la producción de quitinasas en $T$. harzianum.

Por otra parte, el análisis de correlación muestra mediana asociación entre el área de difusión de metabolitos y el crecimiento de $F$. oxysporum $(\mathrm{R}=0.3754)$. Esto sugiere que el efecto en la reducción de crecimiento de $F$. oxysporum sobre metabolitos secundarios de Trichoderma más quitosan no depende de la cantidad de metabolitos difundidos en el medio, si no, de otros factores tales como la concentración y tipo de metabolitos segregados y la dosis de quitosan agregada (Figura 2).

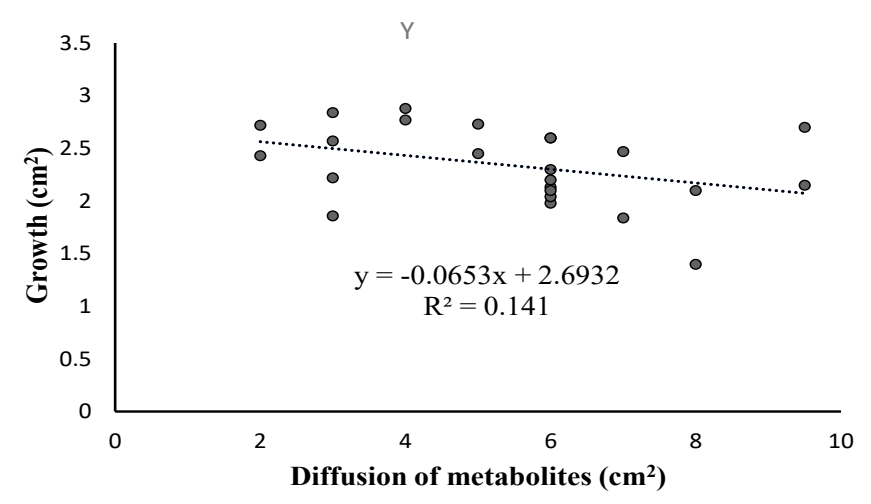

Figure 2. Association between the diffusion of secondary metabolites of $T$. parareesei in SDA with different doses of chitosan and the growth area of $F$. oxysporum.

Figura 2. Asociación entre la difución de metabolites secundarios de $T$. parareesei en SDA con diferentes dosis de quitosan y el área de crecimiento de $F$. oxysporum. 
According to this result, Abou et al. (2007) mentioned that the increase in the antagonistic action of mutant strains obtained from treatments with doses of chitosan may be the result of an increase in the concentration of secondary metabolites, and as mentioned Hermosa et al. (2014), Trichoderma produces hydrolytic enzymes such as $\beta-1,3$-glucanase and chitinases in addition to proteinase enzymes which affect the growth of other fungi such as $F$. oxysporum.

With respect to the growth area of $F$. oxysporum in the presence of metabolites of $T$. parareesei plus chitosan, a synergistic effect was determined at doses of $6 \mathrm{mg}$ $\mathrm{mL}^{-1}$ and $12 \mathrm{mg} \cdot \mathrm{mL}^{-1}$, since growth decreased when adding these two components in contrast to the use of chitosan alone (Table 2), which was also observed when comparing the control $F$. oxysporum grown only in metabolites.

Results obtained by Erayya et al. (2018) on mixtures assays, indicate that the optimum dose of copper hydroxide and chitosan to be used in combination with Trichoderma is 250 to $500 \mathrm{ppm}$ to effectively control the plant disease. While Chittenden \& Singh, (2009) showed that the combination of Trichoderma harzianum and chitosan inhibited spore germination and therefore colony formation as compared using chitosan alone, which only retards germination.

On the other hand, this synergistic action did not occur with doses of $8 \mathrm{mg} \cdot \mathrm{mL}^{-1}$ and $10 \mathrm{mg} \cdot \mathrm{mL}^{-1}$, which could be explained by the existence of unstable mutant strains that
De acuerdo con este resultado, Abou et al. (2007) menciona que el incremento en la acción antagónica de cepas mutantes obtenidas de tratamientos con dosis de quitosan puede ser resultado de un incremento en la concentración de metabolitos secundarios, y como menciona Hermosa et al. (2014), Trichoderma produce enzimas hidrolíticas tales como $\beta$-1,3-glucanasa y quitinasas además de enzima proteinasa las cuales afectan el crecimiento de otros hongos tales como F. oxysporum.

Con respecto al área de crecimiento de $F$. oxysporum en presencia de metabolitos de $T$. parareesei más quitosan se determinó un efecto sinergísta en dosis de $6 \mathrm{mg} \cdot \mathrm{mL}^{-1}$ y 12 $\mathrm{mg} \cdot \mathrm{mL}^{-1}$ debido a que hubo menor crecimiento al sumar estos dos componentes a diferencia de usar sólo quitosan (Tabla 2), lo que también se observa al comparar el testigo F. oxysporum crecido solo en metabolitos.

Resultados obtenidos por Erayya et al. (2018) al hacer mezclas, indican que la dosis óptima del hidróxido de cobre y quitosan para usarse en combinación con Trichoderma es de 250 a 500 ppm para dañar efectivamente la enfermedad de la planta. Mientras que Chittenden \& Singh, (2009) muestran que la combinación de Trichoderma harzianum y quitosán inhiben la germinación de esporas y por lo tanto la formación de colonias a diferencia de usar solo quitosan, el cual únicamente retarda la germinación.

Por otra parte, esta acción sinérgica no se presentó con las dosis de $8 \mathrm{mg} \cdot \mathrm{mL}^{-1}$ y $10 \mathrm{mg} \cdot \mathrm{mL}^{-1}$ lo que pudo ser resultado de la existencia de cepas mutantes inestables

Table 2.

Interaction between the combination of $T$. parareesei metabolites and chitosan doses on the growth efficiency of $F$. oxysporum

Tabla 2.

Interacción entre la combinación de metabolitos de $T$. parareesei y dosis de quitosan sobre la eficacia de crecimiento de $F$. oxysporum

\begin{tabular}{lcc}
\hline \multicolumn{1}{c}{ Treatment } & $\begin{array}{c}\text { Synergistic } \\
\text { factor }\end{array}$ & Interaction \\
\hline T. parareesei metabolites $\left(T p 3\right.$ and chitosan $1 \mathrm{mg} \cdot \mathrm{mL}^{-1}(\mathrm{Qs} 11)$ & 0.81 & Antagonistic \\
T. parareesei metabolites and chitosan $\left(4 \mathrm{mg} \cdot \mathrm{mL}^{-1}\right)$ & 1 & Additive \\
$T$. parareesei metabolites and chitosan $\left(6 \mathrm{mg} \cdot \mathrm{mL}^{-1}\right)$ & 1.18 & Synergistic \\
$T$. parareesei metabolites and chitosan $\left(8 \mathrm{mg} \cdot \mathrm{mL}^{-1}\right)$ & 0.96 & Antagonistic \\
T. parareesei metabolites and chitosan $\left(10 \mathrm{mg} \cdot \mathrm{mL}^{-1}\right)$ & 0.84 & Antagonistic \\
T. parareesei metabolites and chitosan $\left(12 \mathrm{mg} \cdot \mathrm{mL}^{-1}\right)$ & 1.1 & Synergistic \\
\hline
\end{tabular}


showed different results. According to Abou et al. (2007), at doses higher than 3 and $4.5 \mathrm{mg} \cdot \mathrm{mL}^{-1}$ of chitosan, the occurrence of mutant strains of $T$. harzianum is promoted, however genetically unstable strains are more proliferative. This suggests that the stable mutants will express their antagonistic action on $F$. oxisporum with the proviso that action of the unstable mutants will not be predictable.

\section{Conclusions}

The dose of chitosan that reduced the area of growth of the phytopathogen was of $12 \mathrm{mg} \cdot \mathrm{mL}^{-1}$ and did not affect the growth of Trichoderma allowing the liberation of metabolites which occupied an area superior to $7.0 \mathrm{~cm}^{2}$. Although this was not related to the reduction of Fusarium growth, the synergistic effect was observed between the doses 6 and $12 \mathrm{mg} \cdot \mathrm{mL}^{-1}$ and the metabolites diffused in the SDA medium. Information about the antagonistic, additive or synergistic action of the secondary metabolites of Trichoderma plus the effect of chitosan allow us to propose mixtures of these two agents, which will potentially generate a positive effect in the control of phytopathogenic fungi as Fusarium, since the behavior of both antagonists and the phytopathogen can be predicted, however, the effect of chitosan in the stimulation of the plant defensive system is one of the factors that is necessary to consider when applying these mixtures. las cuales mostraron resultados diferentes. De acuerdo a Abou et al. (2007) a dosis mayores a 3 y $4.5 \mathrm{mg} \cdot \mathrm{mL}^{-1}$ de quitosan se induce la existencia de cepas mutantes de $T$. harzianum, pero proliferan más aquellas que son genéticamente inestables. Esto sugiere que las mutantes estables expresarán su acción antagónica sobre $F$. oxisporum pero no resultará predecible la acción de las mutantes inestables.

\section{Conclusiones}

La dosis de quitosan que redujo el área de crecimiento del fitopatogeno fue de $12 \mathrm{mg} \cdot \mathrm{mL}^{-1}$, dicha dosis no afecto el crecimiento de Trichoderma, y permitió la liberación de metabolitos los cuales ocuparon un área superior a 7.0 $\mathrm{cm}^{2}$, aunque esta no estuvo relacionada con la reducción de crecimiento de Fusarium, si se observó efecto sinergísta entre las dosis 6 y $12 \mathrm{mg} \cdot \mathrm{mL}^{-1}$ y los metabolitos difundidos en el medio SDA. El conocimiento de la acción antagónica, aditiva o sinergísta de los metabolitos secundarios de Trichoderma más el efecto del quitosan permite proponer mezclas de éstos dos agentes, las cuales tendrán la certeza de generar un efecto positivo en el control de hongos fitopatógenos como Fusarium, ya que se conocerá el comportamiento tanto de antagonistas como del fitopatógeno, sin embargo, el efecto del quitosan en la estimulación del sistema de defensa de la planta es una de los factores que es necesario considerar al aplicar este tipo de mezclas.

\section{References}

Abou, S. N. A., Abd-El-Aal, S. K. H. and Saha, A. F (2007). The Mutagenic Activity of Chitosan and its Effect on the Growth of Trichoderma harzianum and Fusarium oxysporum f. sp. Sesami. Journal of Applied Sciences Research, 3 (6): 450-455. http://www.aensiweb.com/old/jasr/jasr/2007/450-455.pdf

Alfonso, C., Del Amo, F., Nuero, O. M. and Reyes, F. (1992). Physiological and biochemical studies on Fusarium oxysporum f.sp. lycopersici race 2 for its biocontrol by nonpathogenic fungi. FEMS Microbiology Letters, 99(2-3): 169-174. https://doi.org/10.1111/j.1574-6968.1992.tb05561.x

Al-Hetar, M. I., Zainal, A. M. A., Sariah, M. and Mui-Yun, W. (2011) Antifungal Activity of Chitosan against Fusarium oxysporum f. sp cubense. Journal of Applied Polymer Science, 120 (4):2434-2439. https://doi.org/10.1002/app.33455

Allan, R. C. \& Hadwiger, L. A. (1979) The fungicidal effect of chitosan on fungi of varying cell wall composition. Micología experimental, 3(3): 285-287. https://www.sciencedirect.com/science/article/pii/S0147597579800547

Chittenden, C. \& Singh, T. (2009) In vitro evaluation of combination of Trichoderma harzianum and chitosan for the control of sapstain fungi. Biological Control, 50 (3): 262-266. https://doi.org/10.1016/j.biocontrol.2009.04.015

De Granada, E. G., Orozco De Amezquita, M. C., Bautista Mendoza, G. R. and Valencia Zapata, H. A. (2001) . Fusarium oxysporum El Hongo que nos falta conocer. Acta Biológica Colombiana, 6 (1): 7-25. https://revistas.unal.edu.co/ index.php/actabiol/article/view/63462

Erayya, Shukla, N., Balodi, R., Tewari, A. K. and Kumar, J. (2018) Compatibility of Trichoderma with Copper-Chitosan Graded Combinations, Plant Disease Research, 35 (1): 2249-8788. http://doi.org/10.5958/2249-8788.2020.00008.6 
Guo, Z., Chen, R., Xing, R., Liu, S., Yu, H., Wang, P., Li, C. and Li, P. (2006). Novel derivatives of chitosan and their antifungal activities in vitro. Carbohydrate Research, 34 (3): 351-354. https://doi.org/10.1016/j.carres.2005.11.002

Hermosa, R., Cardoza R. E., Rubio, M. B. and Gutiérrez, S. (2014) Chapter 10 - Secondary Metabolism and Antimicrobial Metabolites of Trichoderma. Biotechnology and Biology of Trichoderma, 125-137. https://doi.org/10.1016/B9780-444-59576-8.00010-2

Hernández-Lauzardo, A. N., Bautista-Baños M. S., Velázquez-del Valle, M. G., Méndez-Montealvo, M. G., Sánchez-Rivera, M. M. and Bello-Pérez, L. A. (2008). Antifungal effects of chitosan with different molecular weights on in vitro development of Rhizopus stolonifer (Ehrenb.:Fr.) Vuill. Carbohydrate Polymers, 73 (4): 541-547. https://doi. org/10.1016/j.carbpol.2007.12.020

Kowsari, M., Motallebi, M. and Zamani, M. (2014) Protein Engineering of Chit42 Towards Improvement of Chitinase and Antifungal Activities. Curr Microbiology, 68:495-502. https://doi.org/10.1007/s00284-013-0494-3

Lárez V. C. (2008). Algunas potencialidades de la quitina y el quitosano para usos relacionados con la agricultura en Latinoamérica. UDO Agrícola, 8 (1): 1-22. http://www.bioline.org.br/pdf?cg08002

Melia, S. \& Aryantha, I. N. P (2010) The Effects of Chitosan on Antifungal Activity of Trichoderma harzianum Rifai against Fusarium oxysporum. The 2nd International Biotechnology \& Biodiversity Conference (BIOJOHOR 2010), Malaysia. https://www.researchgate.net/publication/259335372_The_Effects_of_Chitosan_on_Antifungal Activity of Trichoderma harzianum Rifai against Fusarium oxysporum

Palma-Guerrero, J., Jansson, H., Salinas, J. and Lopez-Llorca, J. V. (2008). Effect of chitosan on hyphal growth and spore germination of Plant. Journal of Applied Microbiology, 104 (2): 541-553. http://doi.org/10.1111/j.13652672.2007.03567.x

Prapagdee, B., Kotchadat, K., Kumsopa, A. and Visarathanonth, N. (2007). The role of chitosan in protection of soybean from sudden death syndrome caused by Fusarium solani f. sp. glycines. Bioresour Technology, 98 (7): 1353 1358. https://doi.org/10.1016/j.biortech.2006.05.029

Rabea, E. I., Badawy, M. E. I., Steurbaut, W. and Stevens, C. V. (2009). In vitro assessment of N-(benzyl) chitosan derivatives against some plant pathogenic bacteria and fungi. European Polymmer Journal, 45(1): 237-245. https://doi. org/10.1016/j.eurpolymj.2008.10.021

Roller, S. \& Covill, N. (2000) The antimicrobial properties of chitosan in mayonnaise and mayonnaise-based shrimp salads. Journal Food Protection, 63 (2): 202-209. https://www.ncbi.nlm.nih.gov/pubmed/10678425

Sandhya, C., Madhayan, K. N. and Pandey, A. (2005) Comparative evaluation of neutral protease production by Aspergillus oryzae in submerged and solid-state fermentation. Process Biochemistry, 40(8): 2689-2694. https://doi. org/10.1016/j.procbio.2004.12.001

Singh, T., Vesentini, D., Singh, A. P. and Daniel, G. (2008). Effect of chitosan on physiological, morphological, and ultrastructural characteristics of wood-degrading fungi. International Biodeterioration \& BiodegradationInt, 62(2): 116-124. https://doi.org/10.1016/j.ibiod.2007.09.006

Xu, X. M., Jeffries, P., Pautasso, M. and Jeger, M. J. (2011). Combined use of biocontrol agents to manage plant diseases in theory and practice. Phytopathology, 101(9):1024-1031. https://apsjournals.apsnet.org/doi/pdf/10.1094/ PHYTO-08-10-0216 